\title{
Itinerarios de la canción. Poesía y antologías a la luz de Las Españas (1946-1956)
}

\author{
Song Routes. Poetry and Anthologies through \\ Las Españas (1946-1956)
}

\author{
Angélica López Plaza \\ Universidad Nacional Autónoma de México \\ anlopez@colmex.mx \\ ORCID iD: http://orcid.org/0000-0003-0752-7094 \\ Conrado J. Arranz \\ El Colegio de México \\ cjarranz@colmex.mx \\ ORCID iD: http://orcid.org/0000-0001-8736-623X
}

\section{RESUMEN}

El objeto de este estudio es analizar el complejo diálogo que se produjo entre la poesía de posguerra española de uno y otro lado del Atlántico. Una reflexión crítica sobre la posible comunicación que se generó por medio de la poesía del exilio español y la poesía peninsular de posguerra nos ofrece una muestra de una afinidad mayor a la que supone la crítica. De esta forma, se intenta matizar el tópico de la incomunicación de las dos Españas; y se formulan los posibles itinerarios, rutas e intercambios poéticos que se produjeron entre la revista del exilio español en México titulada Las Españas (1946-1956) y distintas antologías publicadas en la península. En este orden de ideas, se estudian las poéticas de escritores como Gabriel Celaya, Victoriano Crémer, León Felipe, Juan Rejano, entre otros.

Palabras Clave: canción; poesía de posguerra; exilio.

\section{ABSTRACT}

The purpose of this study is to analyze the complex dialogue that occurred between the poetry of Spanish postwar either side of the Atlantic. A critical reflection on the possible communication that occured by the poetry of Spanish exile and by the poetry of peninsular postwar imply an greater affinity. In this way, we analyze the wrong topic of the isolation of the two Spains; and also we analyze the itineraries, routes and poetic exchanges that occurred between the magazine of the Spanish exile in Mexico entitled Las Españas (1946-1956) and various anthologies published in the Peninsula. In this article, we also studied the poetics of writers like Gabriel Celaya, Victoriano Cremer, León Felipe, Juan Rejano and others.

Key words: Songs Routes; Poetry of Postwar; Exile. 
La mayoría de los estudios sobre la poesía española de estos años han afirmado la aparente desvinculación o incomunicación de los escritores de «la España peregrina» frente a los escritores de la «España cautiva» —al decir de José Bergamín-, también es cierto que existen diálogos, muchas veces polémicos y otras tantas elogiosos, pero siempre productivos, entre unos y otros ${ }^{1}$. Sin embargo, una reflexión crítica sobre la posible comunicación que se generó por medio de la poesía del exilio español y la poesía peninsular de posguerra nos ofrece una muestra de una afinidad mayor a la que supone la crítica.

Imágenes como la España dolida, la muerte y la soledad, tanto como la esperanza, la añoranza y la imprecación a Dios son algunas de las propuestas poéticas que encontramos en los dos grupos de escritores. Una de las líneas poéticas de mayor relevancia, que comparten ambos grupos, consiste en situar el problema de España dentro de una reflexión más amplia sobre la condición humana. En este sentido, la poética y las reflexiones éticas de Antonio Machado resultan evidentes en ambos grupos de escritores. También se perfilan matices y diferencias muy marcadas en lo que respecta al tratamiento del tiempo (pasado-futuro), la voz poética (yo-nosotros) y temas como «la actualidad española» o la realidad vivida por cada uno a raíz de la guerra, particularmente los aspectos cotidianos de la experiencia del desarraigo geográfico, íntimo, social y, en última instancia, vital. De todas formas, el lenguaje poético empleado por unos y otros resulta iluminador en lo que respecta al diálogo iniciado desde el destierro. El diálogo gradual que se generó por parte de los exiliados en distintos foros, ya fuesen revistas, periódicos o antologías de la época, marcó una nueva etapa tanto para la experiencia del destierro español cuanto para la experiencia del cautiverio.

Quizás, uno de los primeros proyectos del exilio español que, de manera involuntaria al principio, se inserta en esta necesidad de entablar un diálogo con la comunidad intelectual del interior haya sido la revista Las Españas. Dirigida y editada por dos intelectuales exiliados en México, Manuel Andújar y José Ramón Arana, la revista Las Españas fue el proyecto político y literario de mayor duración y alcance en el destierro, en el que participaron escritores y artistas de muy diversas corrientes ideológicas. La publicación se insertó en una tradición hemerográfica del destierro español que provenía de revistas como Romance y España peregrina, y coincidió en 1947 con la publicación de Ultramar. Publicada de forma irregular — veintiocho números que van desde

${ }^{1}$ Entre los pocos estudios que dedican una mirada crítica al tema del diálogo entre la poesía española del exilio y la poética de la posguerra podemos destacar los siguientes: el texto pionero de José María Naharro-Calderón (1986). «La poesía española del exilio y el canon de posguerra: puntualizaciones histórico-críticas», Bulletin Hispanique. 88, 3-4, pp. 385-407; el polémico, pero sugestivo estudio de Paul Ilie (1981). Literatura y exilio interior: escritores y sociedad en la España franquista. Madrid: Fundamentos; y la investigación de James Valender (1998). 
su aparición en octubre de 1946 a julio de 1956-, Las Españas ofreció un espacio de expresión y de diálogo tanto a la comunidad exiliada como, posteriormente, a los poetas del interior de la península ${ }^{2}$.

Uno de los propósitos principales del proyecto consistió en mantener cierta continuidad de la cultura española a pesar de la ruptura que había traído consigo la Guerra Civil. Los desterrados se percibían como los herederos de una tradición, los salvadores y protectores del bien cultural español. Este hecho se entiende, sobre todo, como una estrategia para ganar adeptos de la comunidad internacional y, de esta forma, unir los reclamos para defender a una España asediada por el régimen franquista. Al respecto, las palabras referidas por los directores de la revista en el número inaugural resultan muy reveladoras:

La cultura española ha sufrido solución de continuidad. Detrás de los viejos maestros, y de los que ya empiezan a envejecer, no se ve nada. Da grima leer los periódicos y las revistas que llegan de España; da pena y vergüenza leer a los «poetas jóvenes», a los seudoensayistas y seudofilósofos aupados por el régimen.

España, allí no tiene voz. No puede tenerla mientas el crimen y el desafuero suplanten a la ley; mientras el derecho y la dignidad de los hombres sean pisoteados; mientras la barbarie clerical y castrense disponga a su antojo de haciendas y vidas. Pero España, puede y debe tener voz más allá de sus fronteras; donde quiera que haya un núcleo de españoles viviendo en libertad («Editorial», 1946: 2).

Si entendemos el fenómeno del exilio como un proceso de desgarramiento tanto físico - el traslado forzoso de un país o región a otro- cuanto una separación afectiva del medio sociocultural e identitario al que pertenece el sujeto, entonces comprenderemos mejor las posturas un tanto categóricas que en la década del cuarenta comenzaron a desarrollarse en el marco de la comunidad de intelectuales exiliados en México. Era justificable, pues, que el lenguaje utilizado fuera concluyente e inapelable. La posibilidad de reconocer algún tipo de expresión literaria o cultural que proviniese de la España del interior no era una opción para los intelectuales españoles que estaban «peregrinando por el mundo», más bien iba contra sus imperativos de salvaguardar los valores culturales. «Nuestra revista aspira a ser un instrumento más en la reconquista y reconstrucción de España, en la difusión de nuestra cultura»-explicaron, nuevamente en el primer número de la publicación (Redacción, 1946: 7). Al respecto, la estructura de Las Españas, respondía por completo a esta instrumentación ideológica, también la primera sección de poesía — «Poetas ibéricos»-, donde predominaba el criterio taxonómico de la España confederal, que incluso procuraba dar cabida a producciones poéticas en diferentes lenguas del territorio español. El propio Manuel Andújar lo reconocería en una entre-

2 Para un estudio completo sobre la revista Las Españas véase Valender y Rojo Leyva (1999). 
vista posterior: «El criterio general, que observamos mientras yo formé parte, como fundador también, de la dirección de la revista, se atenía a un predicado de amplia representación cultural, democrática, confederal; de ahí el propio título, plural, de la publicación» (Andújar, 1999: 300). Como veremos a lo largo de este trabajo, el contenido poético nos mostrará nuevos caminos para la revista, acorde tanto con la propia producción en el exilio y en el interior, como con los diferentes acontecimientos históricos.

Las Españas partía de la premisa, como queda evidenciado en el primer editorial, de que la tradición cultural española le pertenecía a la comunidad del éxodo. De ahí la necesidad de adueñarse de la voz frente al silencio de los otros, ya fuesen «intelectuales amordazados» o aquellos encumbrados por el franquismo. El contraste entre una España peninsular carente de voz, que es lo mismo que de palabra y tradición, frente a una España sin fronteras en donde cada español tenía el privilegio al grito, a la blasfemia, al canto, fue uno de los esquemas valorativos que se desarrolló en gran parte de la revista. Sin embargo, un reconocimiento paulatino del camino seguido por la poesía del interior por parte de los colaboradores de la publicación trae consigo, inevitablemente, la urgencia de una nueva percepción y forma de vivir la poesía, tanto como la necesidad de replantearse su papel protagónico en el marco del exilio español.

¿Quién se quedó con la voz, con la canción, con la palabra? Fue un tema que cobró una importancia insospechada a raíz de los versos que León Felipe Camino Galicia —mejor conocido como León Felipe- recitase por primera vez en el Palacio de Bellas Artes de México, en un acto organizado por la Casa de España, en 1939. El conflicto bélico y el trágico drama vivido como consecuencia de la guerra son algunos de los temas centrales de cuanto escribió durante los primeros años del exilio: El payaso de las bofetadas y el pescador de caña (1938), El hacha (1939) y el emblemático poemario Español del éxodo y del llanto (1939). Sin embargo, a pesar de su solidaridad y filiación con el conflicto español, León Felipe fue también uno de los primeros poetas del exilio que se entregó a la búsqueda de un hombre total, más allá de nacionalismos y sectarismos. Estas reflexiones alcanzarían su cenit en el poemario Ganarás la luz (1943), «etapa transitoria en que la poética del autor se mueve hacia el cuestionamiento de su propia identidad y revalorización de la condición humana» (Jato, 2004: 133). Estos planteamientos poéticos y existenciales, que se asemejan a la búsqueda de las expresiones íntimas, vitales y cotidianas del hombre, son algunos de los temas que formarán parte de la llamada «poesía social» de los años de posguerra en la península.

La caja de pandora se abrió cuando León Felipe distribuyó los bienes tanto materiales como espirituales de la patria asediada, y declamó desde la distancia su tan famoso «Reparto»:

La España de las harcas no tuvo nunca poetas. De Franco han sido y siguen siendo los arzobispos, pero no los poetas. En este reparto injusto, desigual y 
forzoso, del lado de las harcas cayeron los arzobispos y del lado del éxodo, los poetas. Lo cual no es poca cosa. La vida de los pueblos, aun en los menesteres más humildes, funciona porque hay unos hombres allá en la Colina, que observan los signos estelares, sostienen vivo el fuego prometeico y cantan unas canciones que hacen crecer las espigas.

Sin el hombre de la Colina, no se puede organizar una patria. Porque este hombre es tan necesario como el hombre del Capitolio y no vale menos que el hombre de la Bolsa. Sin esta vieja casta prometeica que arrastra una larga cauda herética y sagrada y lleva sobre la frente una cresta luminosa y maldita, no podrá existir ningún pueblo.

Sin el poeta no podrá existir España. Que lo oigan las harcas victoriosas, que lo oiga Franco:

Tuya es la hacienda,

la casa

el caballo

y la pistola.

Mía es la voz antigua de la tierra.

Tú te quedas con todo

y me dejas desnudo y errante por el mundo...

mas yo te dejo mudo... ¡Mudo!

¿Y cómo vas a recoger el trigo

y a alimentar el fuego

si yo me llevo la canción? (León Felipe, 1963: 120).

El dolor de la pérdida de España unido al choque emocional y cultural que supone el exilio, hacen que León Felipe necesite adueñarse de la palabra poética para expresar su angustia existencial. En estos versos, escritos al calor del destierro, el poeta divide al país en dos Españas irreconciliables: por un lado, la España fratricida de Franco, la del capitolio, la bolsa y los arzobispos, y, por otro lado, esa patria errante, la España desnuda y vagabunda que se ha llevado consigo la voz, la canción. La división de los bienes del terruño, desde luego, entraña cierta violencia e injusticia con aquellos que se quedan en la patria sitiada. Sin embargo, y a pesar de que las palabras utilizadas por el poeta son tajantes y excluyentes, el poema debe ser entendido en el contexto global de la poética del exilio, sobre todo en lo que respecta a los primeros años del destierro.

El desarraigo que provoca la salida forzosa de la tierra natal y la subsecuente pérdida de identidad se reflejan en la imagen poética tierra-canción, un recurso poético que encontraremos en muchos poetas del éxodo español. La tierra, antaño vinculada con una tradición poética, es ahora dejada atrás; y el hombre de la Colina, ese hombre identificado como el poeta del éxodo, el que se ha llevado el fuego y la canción, también lleva consigo a la patria. Así pues, una de las estrategias que tuvieron que adoptar los exiliados para sobrevivir en el destierro fue, sin duda, adueñarse de lo único que la guerra y la dictadura franquista no les pudieron quitar, con lo único que contarían en la nueva patria 
de adopción: la palabra, el derecho al canto. Dialéctica que para los poetas del interior se complicaba debido a la censura. Aunque cabría resaltar que sería, precisamente, el poema el espacio idóneo y predilecto para burlar la inspección del régimen.

Pero la voz parece ser frágil y el canto se tambalea entre una esperanza incierta y una congoja desoladora. La exhortación hecha por el poeta es puesta en duda por la propia voz poética:

Españoles del éxodo y del llanto:

levantad la cabeza

y no me miréis con ceño,

porque yo no soy el que canta la destrucción

sino la esperanza (León Felipe, 1963: 125).

Luego de haber proclamado la salvación de la patria por medio del canto, ese canto errabundo del hombre de la Colina, el poeta proclama el exterminio del terruño:

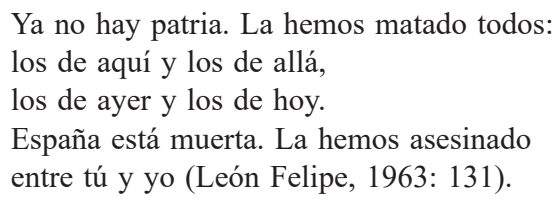

La contradicción que persiste en el canto del poeta es sumamente reveladora. Refleja, desde luego, la angustia del hombre ante la desgarradora realidad. Pese a que la canción le pertenece a la comunidad de españoles errantes o desterrados, la destrucción de la patria es responsabilidad de todos, tanto del español de allá como del de acá. Los titubeos poéticos incrementan y, en el mismo poemario, el cantor declara no tener patria:

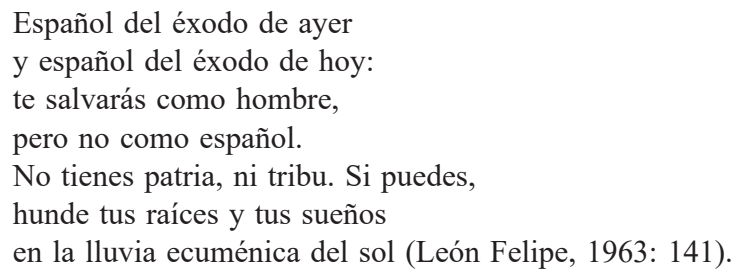

De esta sentencia se harán eco los poetas de la España cautiva. El español dejaría de tener una nacionalidad impregnada de patriotismo ideológico y adquiriría un visado universal. No es casualidad que Ganarás la luz (1943), poemario escrito en los años posteriores a la euforia del canto de Español del éxodo y el llanto, comience con las «blasfemias de un caminante». El poeta indaga cómo se llama y emprende la búsqueda de su propio nombre. La pre- 
gunta que rige la estética del poemario es significativa: «¿quién soy?». Este interrogante presupone el abandono de la propia identidad para emprender un camino incierto. La respuesta está relacionada con la necesidad de reconocerse y, por ende, de encontrar una voz apropiada para ese hombre: «Yo no soy nadie: / un hombre con un grito de estopa en la garganta / y una gota de asfalto en la retina» (León Felipe, 1963: 189).

El poeta vuelve a contradecirse. A pesar de declarar que ahora es un hombre con un grito deshecho, vuelve a recalcar que existen dos Españas y «una sola canción»: «Y la España que se llevó la canción, se llevó el salmo también» (León Felipe, 1963: 194). La diferencia entre esta imagen y la utilizada con anterioridad en 1939 estriba, precisamente, en el cambio de tono que utiliza el autor. Las fluctuaciones poéticas entre el primer poemario y este gravitan en que ya no es el español del éxodo quien canta, sino el hombre común el que grita y blasfema la palabra poética.

Pero el autor de El ciervo no es el único que por aquellos años se auto-proclama como el dueño de la Palabra frente al mutismo de los otros. Juan Rejano en «Enardecida sombra», poema escrito entre París y México, camino al exilio en 1939, también expresa su doloroso sentimiento de pérdida y desarraigo mediante la evocación de una voz que «ya no tiene otros límites / que sus propias raíces». Y proclama el silencio y la muerte de la palabra del otro:

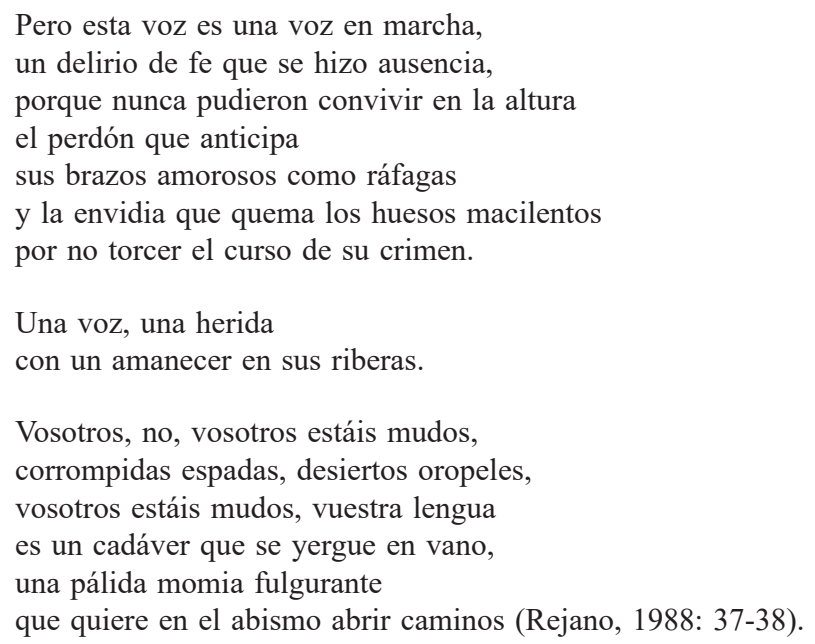

Las Españas se hizo eco de este sentimiento generalizado por parte de la mayoría de los exiliados españoles durante los primeros años del exilio, y pregonó en sus páginas la supremacía de la voz, de la tradición poética y literaria de la comunidad del éxodo.

Un recorrido por los primeros números de la revista evidencia que existía una noción salvadora por encima del interés en la muy discutible cultura que 
se desarrollaba en la España cautiva. Los dos géneros literarios en donde mejor se vislumbran las dubitaciones o fluctuaciones en torno al diálogo entre los escritores exiliados y los del interior son, por un lado, el ensayo - tanto en su vertiente creativo-literaria como en la de reseña crítica-y, por otro, la poesía. En ambos casos, se mantienen las perspectivas históricas, políticas, sociales y personales de aquellos que vivieron el éxodo. Sin embargo, las propuestas y los enfoques desarrollados en cada género muestran diferencias sustanciales que es necesario precisar.

El ejercicio de la crítica, en tanto discriminación, valoración y ponderación de los textos seleccionados dicta cierta forma de lectura y presenta los libros que deberían formar parte de un canon o tradición literaria. De ahí que las reseñas representen quizás el espacio más adecuado tanto para la condenación y rechazo de la producción poética de la península como para el elogio y acogimiento de ciertas obras poéticas. En Las Españas la sección titulada Los Libros estuvo destinada a esta labor crítica. Si bien es cierto que se reseñaron novelas del interior como Nada de Carmen Laforet y textos narrativos como Esas nubes que pasan de Camilo José Cela, el blanco predilecto de ataque lo constituyeron en su mayoría las obras poéticas. Vicente Aleixandre y Dámaso Alonso fueron las dos figuras clave que formaron el epítome del escarnio por parte de muchos intelectuales del exilio español en México $^{3}$. Un claro ejemplo de este menosprecio y, por tanto, de cierta incomprensión por parte de la comunidad de intelectuales exiliados hacia la poética del interior lo expuso de forma muy clara María Dolores Arana en la reseña que hizo del poemario Sombra del paraíso (1944).

\begin{abstract}
A través de su lectura - sentimientos y sensaciones transfigurados en conceptos líricos- nos encontramos con esa permanente tendencia del poeta por abstraerse en la intimidad, mundo o reino que se ha creado y que cuidadosamente nutre de su propia sustancia, de su propia sangre, de su propio aliento, pero en el que apenas si encontramos resonancias del mundo sustantivo de las cosas vivas, ni solidaridad con el dolor común de los hombres.

Estetismo egoísta. Creación admirable de la inteligencia.

Pero hoy esto no basta. Mejor dicho no nos basta. No olvidemos que el arte, en este caso concreto la poesía, no es simple afán sensual de goce y dolor subjetivos [...] sino que necesita también creer o lo que es igual, sentirse parte encendida en el drama del mundo (Arana, M. ${ }^{a}$ Dolores, 1947: 4).
\end{abstract}

\footnotetext{
3 James Valender y Gabriel Rojo Leyva (1999: 260) enumeran algunos de los textos escritos desde el exilio mexicano en que los autores censuraron fuertemente la figura de Dámaso Alonso. Véase: Rejano, Juan (1946). «Los poetas en la cárcel. Tres poetas en desamparo, de Dámaso Alonso», Letras de México. 119, 1-I-1946, p. 205; García Nazareno, Gabriel (1948). «Carta abierta a Dámaso Alonso», El Nacional (México). 17-XI-1948, p. 5; y Aub, Max (1950). «Carta abierta a Dámaso Alonso», Sala de Espera (México). 23, pp. 1-7.
} 
Para Dolores Arana, la poesía española debía ser, aun en 1947, un arma de combate frente al drama histórico que se vivía. Un refugio que, si bien albergaría al hombre de las injusticias y de la dolorosa realidad imperante, no podría ser un albergue de uno solo, sino el espacio común de todos los hombres. Pese a la «abstracción intelectual» con la que se describen los recursos poéticos utilizados por Vicente Aleixandre, la reseñista elogia lo que considera cierta contradicción que está presente en el poema; contradicción que - comenta«no podemos negar valor humano, especie de mezcla compleja entre la evasión y la búsqueda, entre la alegría y la desilusión, entre la vida y la muerte». Pero, ¿acaso la poesía escrita en el destierro - como toda poesía- no se nutre precisamente de esa tendencia por abstraerse a la intimidad, a la memoria del tiempo perdido, a la evocación de un yo que no encuentra comunión con los otros; y a esa contradicción humana entre vida y muerte? Las valoraciones negativas que se hacían del quehacer literario del interior de España eran, pues, un tanto injustas, en lo que respecta a los juicios críticos de la poesía escrita en el destierro. Esta última pecaba de las mismas deficiencias «esteticistas», que para Dolores Arana no eran suficientes en la poesía del interior. Con excepción de poemas como «Raposa», fragmento de la elegía La insignia (1937) de León Felipe, y «Pueblos libres, ¿Y España?» de Rafael Alberti de temática explícitamente política, el resto de los poemas escritos en el destierro, que aparecen publicados en la revista, recrean una nostalgia que se retrotrae del «drama del mundo»; presentando, así, la tragedia de su propia individualidad. Un claro ejemplo de esta ambivalencia crítica y de estos prejuicios por parte de los ensayistas de Las Españas se refleja en el poema «A veces oigo» de José Moreno Villa.

A veces oigo los pétalos de la rosa dando en tierra; tan tirante es el silencio, tan en aviso está el alma.

A veces oigo la fuga de la luna en su viraje; tan grande es la soledad, tan tenso vive el espíritu.

A veces oigo la arena del Tiempo caer en mí... Me levanto, me paseo, toco la estampa o el libro, miro la luz de la lámpara, me froto las tibias manos y me siento, lentamente, a ver cómo la de arriba está casi toda abajo (Moreno Villa, 1946: 1). 
Los recelos con que algunos ensayistas de Las Españas analizan la producción poética del interior se hacen más palpables y se recrudecen con la visión, bastante polémica, de José Ramón Arana. Además de los editoriales escritos por la pluma de este escritor, encontramos un texto de su autoría que resume el pensamiento más virulento del proyecto hemerográfico, particularmente en lo que respecta al diálogo entre la poesía del interior de España y la del destierro. En el ensayo titulado «Voces, ecos y sombras», publicado unos meses después de la reseña comentada anteriormente —enero de 1947- Ramón Arana analiza una de las antologías publicada por esos años en España, en este caso, la Antología de poetas españoles contemporáneos (1946), editada por César González Ruano. Más allá de proponer un análisis sobre la antología, lo que nos interesa demostrar aquí es cómo los juicios negativos que Arana asocia con la «generación sin vertebras» - al decir del propio ensayista- pueden ser elementos de comparación para entender el camino estético trazado por la poesía de los desterrados.

Así pues, confrontar la temática de los ensayos con la poesía publicada en Las Españas puede arrojar luz sobre la idea que se tenía del quehacer literario en el interior de la península frente a la obra realizada por los propios escritores en el destierro. Como hemos visto hasta el momento, el diálogo emprende una sola vía, el camino inquisitivo y escéptico que mantuvieron los españoles peregrinos frente a los del cautiverio. Aunque esta valoración fue matizándose con el pasar de los años. La temática del ensayo va dirigida a analizar el quehacer literario español a través de su historia. Ramón Arana, con una pluma muy sarcástica y aguda, comenta paso a paso las distintas características poéticas de cada generación literaria, con especial énfasis en la literatura escrita a partir de la pérdida de la guerra civil y del comienzo de la dictadura franquista. «Importa, la última parte de su libro — comenta el ensayista- y nos importa como documento, como ventana abierta sobre el paisaje humano más reciente, incógnito para nosotros». Pese a que reconoce el desconocimiento que muchos exiliados poseen hacia la obra literaria escrita en la península, su crítica no deja de ser convencional. Ramón Arana se hace eco de los versos de León Felipe para justificar que a partir de la muerte del poeta Miguel Hernández, «aquella gran voz de España», allí «no hay más que ecos de ecos, sombras de sombras chorreando lágrimas, bisbiseando responsos y elegías». Y añade:

Envuelta en esa nada poética, en ese cero humano, hay un grumo de sangre que quiere huir, que se asoma por momentos al ventanal que da sobre la vida, y que sintiéndola imposible, desfallece y se hunde otra vez en el vacío. ¿Qué está pasando en España? ¿A qué responde esta generación sin vértebras, sin nervio, donde resuena, como en una gran oquedad, todo lo que gime y se deshace, y ni siquiera un rumor de nuestra furia, un eco de blasfemia, de grito, que denuncien vida sublevada? (Arana, 1947: 11). 
La pasión con que Ramón Arana describe el quehacer literario y artístico de los intelectuales en el exilio nos resulta llamativa. Según el ensayista, furia, blasfemia y grito son algunos de los elementos estéticos que deben adquirir los escritores del interior para mostrar ciertos rasgos de vida. Nuevamente, el referente utilizado para juzgar la producción literaria de la península es el motivo de la canción — de la palabra - frente al mutismo, la oquedad y el sollozar de escritores con «venas vacías, y en las manos, a cuenta de sangre, un viento de palabras». Sin duda, el referente poético que Arana tiene presente al momento de valorar la creación poética de la España en cautiverio, como hemos señalado anteriormente, es la figura de León Felipe. En la revista, en cambio, el canto furioso no es lo que prima. Una mirada por la sección titulada «Poesía en el destierro» —-sección que por cierto apareció hasta el número nueve de la publicación- o por los poemas sueltos a través de las distintas páginas del proyecto hemerográfico revela la ausencia de ese canto rebelde y desafiante.

En ese esguince de perfil —el lado patético y en fuga de tu instable vida a muerte-, aleznado y deleznable, vas con tu voz de tinta, emborronado.

Se da a tu sombra en vilo, de arrancado con ira y de raíz, lo que no es dable: apenas, sólo, el sitio indispensable en que apoyar el pie desarraigado (Domenchina,1949: 8-9).

Los versos de Juan José Domenchina en el texto titulado «La sombra desterrada» y los ensayos que hemos analizado hasta el momento, evidencian dos rasgos fundamentales sobre la noción que de la experiencia del exilio se tenía en la revista. Por un lado, los ensayistas mantenían una percepción más combativa y un tanto idílica sobre lo que significaba ser un intelectual en el exilio, y sobre su papel en la reconstrucción de la España libre; mientras que para los poetas el saberse exiliados equivalía a una situación límite, a un momento de crisis muy difícil de superar. De ahí el tema tan recurrente en la poética de estos años: la añoranza del pasado frente a un presente muy incierto. Incluso para los poetas más jóvenes, aquellos que salieron acompañando a sus padres en la travesía del éxodo, la nostalgia y la pérdida de la tierra natal serán uno de los motivos de su cantar en el exilio. Tal es el caso de Luis Rius Azcoitia y su canto nostálgico por la República perdida. En «Paisaje» el poeta dice: «canta una canción sombría / la callejuela del pueblo: canción de tristeza y llanto, / canción de color de muerto» (Rius, 1946: 6).

Manuel Durán Gili, poeta de esta segunda llamada generación del exilio, también publica en Las Españas. En su poema titulado «Elegía», nos presenta una voz poética que recorre distintos senderos en búsqueda de su tierra. 
Todo se ha cerrado. No es ésta tu patria.

Los tentáculos de amor

se desenrollan, tropiezan,

sacan de su nicho a cada estrella

buscando en ella la canción perdida,

acarician ideas y corazones lejanos.

El corazón y la estrella tienen una misma voz:

Todo se ha cerrado. No es ésta tu patria (Durán, 1947: 13).

En este punto, cabría aclarar que esta noción de vagabundeo y de extrañamiento no sería la única entre los poetas del exilio. Pasado los primeros años de furor por regresar a la patria, y ante la imposibilidad de volver, los poetas comenzarían a integrarse al país que les brindó acogida. En ese sentido, las experiencias vividas en la nueva patria constituirían los nuevos motivos poéticos. Pero volviendo al tema del diálogo de la poesía española entre las dos fronteras, - la España peregrina y la solariega - podríamos concluir que en muchos casos, los ensayistas que colaboraron en Las Españas intentaron trazar una línea de pensamiento que los poetas, tal vez de forma inconsciente, rehusaron seguir.

Otro de los ensayistas destacados en la revista fue Daniel Tapia. Las ideas que este escritor desarrolló fueron bastante cuestionadas y criticadas en el marco político de lo que se entendía como el exilio español. Tapia fue uno de los pioneros, junto con el escritor exiliado Paulino Masip, en proponer una visión progresista o de avanzada en lo relacionado con la condición del exilio. $\mathrm{Su}$ tesis principal se apoyaba en la idea de mirar la nueva realidad como un espacio de porvenir. «Ver para vivir» fue la frase que acompañó algunos de sus mejores textos en Las Españas. Esto equivalía a dejar atrás las ilusiones estériles — según el escritor - de mirar al pasado constantemente; añoranza que, a pesar de su crítica, se volvió un mito para la poética del destierro. «Hemos adquirido un hábito — comentaba en el ensayo "Ver para vivir. La otra mujer de Lot"- y este hábito, el de volver la cabeza atrás, va camino de convertirnos en estatuas de sal» (Tapia, 1948b: 11).

Daniel Tapia y José Ramón Arana también percibieron que era necesario un cambio de rumbo político. El planteamiento de una «política española para el español en el destierro» — al decir de Tapia- contribuyó a la reflexión ideológica que a partir de finales de la década del cuarenta sufriría la comunidad de exiliados republicanos en México. «No demos de lado a España para implorar el reconocimiento o la tutela de quienes, extranjeros, no nos deben nada porque nada de nuestro corazón les hemos dado», vaticinaba Tapia en «Las castañas en el fuego», texto publicado en 1948 (Tapia, 1948a: 10). Dos años después padecerían, efectivamente, las consecuencias de las determinaciones que la comunidad internacional, representada por la ONU, dictaminaría 
a favor de la política franquista. Se trata de una etapa de transición - como señalan Valender y Rojo Leyva- en que los exiliados reconocerían lo que ya habían empezado a intuir unos años antes, a saber: ellos habían perdido el papel protagónico en la lucha antifranquista y en adelante sería el movimiento de resistencia surgido al interior del país quien tendría que tomar las iniciativas (1999: 47-48).

Los augurios de lo que resultó ser una falsa solución al «problema español» calaron hondamente en el pensamiento y espíritu de la comunidad del éxodo. No es de extrañar, por tanto, que la revista se hiciera eco de esta situación. A partir de la década del cincuenta vemos que en las páginas de Las Españas comienza a darse un replanteamiento sobre las críticas tan violentas que habían promulgado en contra de los escritores del interior de la península, en sus primeros números. Ante el panorama desolador al que aludían los críticos y reseñistas, al referirse a la poética del interior sin hacer exclusiones o análisis rigurosos, admiten en 1950 una distinción entre «los intelectuales rentistas de la tradición y los intelectuales que existen y laboran al margen del franquismo» (Redacción, 1950: 13).

El diálogo que había comenzado de forma unilateral y con un tono furibundo es, en este momento de la publicación, expuesto con una mirada más crítica y sosegada. Este diálogo nos hace replantearnos el papel de la revista como una gran antología poética más abierta a las publicaciones que se producían en el interior. Además, Las Españas sufrió un cambio de rumbo importante con la publicación de la Antología consultada de la joven poesía española, a cargo de Francisco Ribes (1952). Como antología poética que en sí misma es y, partiendo de la desvalorización del hecho poético en el interior de España, como ha quedado claro en los primeros números de la publicación, el proyecto hemerográfico prestó especial atención a otras antologías publicadas en dicho territorio. Ya el primer número contuvo un ataque feroz, por parte de Paulita Brook, a la Antología de poetas españoles contemporáneos (Madrid, 1945), de César González Ruano:

Sigue el desfile de poetas más o menos conocidos nuestros, representados por poemas mejor mal que bien elegidos, pasando por el modesto autor que dedica a su obra tantas páginas como a Alberti. Y llegamos, por fin, a la lista de poetas conocidos, que han comenzado su obra bajo el régimen de Franco. En casi todos, un afán inmoderado de escapar a las influencias «indeseables» volviendo los ojos a los modos clásicos. En casi todos, poesía sin alas que renuncia a la audacia del vuelo. Es natural: es un intento de poesía entre rejas, enjaulada, o con las plumas de las alas cortadas, para que no pueda volar muy lejos, ni muy alto (Brook, 1946: 5).

No cabe duda de que la crítica se dirigía en mayor medida hacia la corriente de la poesía española conocida como «garcilasista», el intento por regresar a lo clásico, un viaje a la negación de la realidad, al esteticismo, al ensimisma- 
miento. Frente a esta antología poética peninsular se situó otra: la Antología consultada de la joven poesía española (1952). Esta antología nació a priori con una virtud que la diferencia de la anterior: el autor de la misma parece objetivarse detrás de una consulta a sesenta expertos. Es decir, su trabajo parece haberse ceñido a la elección de lo mejor de cada uno de los poetas elegidos en esta relevante encuesta. El editor, quizá conocedor de las críticas que otras antologías anteriores habían recibido, se cuida mucho de ofrecer al lector esta imagen de objetividad en un texto inicial que titula «El editor se justifica», donde explica cuál era la pregunta dirigida a los expertos: «¿quiénes son, en opinión suya, los diez mejores poetas, vivos, dados a conocer en la última década?» Atrás quedan los poetas que se dieron a conocer antes de la guerra, atrás también los que están publicando por primera vez fuera de España, ya que en la península apenas se tiene conocimiento de ellos. La obsesión por convertir la antología en un documento sociológico importante conduce al editor a incluir en el título la palabra «consultada» y, por ende, clarificar en el interior el nombre de los expertos y el resultado de las votaciones. La única reivindicación que contiene el prólogo es la que se desprende del objetivo de la propia antología:

Por eso no bastaría llegar a los finos de espíritu, a las mentes cultivadas, a las sensibilidades despiertas, y decirles que incurren en grave manquedad, que no tienen derecho a considerarse espirituales ni cultos ni sensibles, si ignoran la muy estimable producción poética de su tiempo. Habría que mostrarles, además, lo que en verdad está logrado, lo que es auténtico, lo que de un modo noble refleja y magnifica ese tiempo (Ribes, 1952: 9).

Queda plasmada nuevamente la necesidad de la poesía para interpretar la realidad histórica del momento y, de manera indirecta, el editor ataca a aquellos que quieren negar una parte fundamental del quehacer poético de su tiempo. La Antología consultada se convierte en ese momento en un faro esencial de la poesía del interior de España, que tiene consecuencias en la línea editorial de Las Españas. La más clara de ellas es la creación de una sección específica dedicada a la muestra de la poesía que se lleva a cabo en el interior y que se llamaría en un primer momento «Balcón de la poesía actual en España», antes de que dos números más tarde cambiara el nombre a «Balcón a la poesía española actual». Esto ocurre precisamente en abril de 1952, cuando se publicaron los números 21-22 de la revista. La sección no perdería su estructura de cosmovisión de la pluralidad lingüística de la península, ya que seguía recogiendo poetas cuyas lenguas maternas eran, por ejemplo, el catalán o el gallego, junto a los que lo hacían en castellano. A partir de ese momento, tres poetas mostrarían sus trabajos en las hojas de Las Españas: Gabriel Celaya, Eugenio de Nora y Victoriano Crémer, aunque este último lo hiciera en virtud de sendas críticas a sus libros La espada y la pared y Libro de Santiago. 
Por el resultado de la Antología consultada observamos también el hastío de una gran parte de la intelectualidad contra el régimen, ya que cinco de los nueve poetas seleccionados - Gabriel Celaya, Blas de Otero, Eugenio de Nora, Victoriano Crémer y José Hierro- habían mostrado en sus composiciones poéticas su enfrentamiento político, su disconformidad, la denuncia social como mecanismo temático. El discurso ideológico que emanaba de esa poética, la lectura de la sociedad del momento, encajaba en la reivindicación del exterior y abría en el seno de Las Españas un proceso de autocrítica que tendría también su reflejo en los ensayos ${ }^{4}$. El momento de la publicación de la antología y su atención por parte del exilio coincidían: abrían una brecha en el interior en cuanto que se trataba de una poesía reivindicativa de la realidad de España y permitía al exiliado comprender la oportunidad histórica, alejados ya de la esperanza de que el mundo interviniera en contra del régimen franquista.

El consejo editorial de la revista hizo una lectura interesada ideológicamente de esta antología. En números anteriores, Las Españas había criticado duramente la antología de César González Ruano, como ya vimos, y también la de Alfonso Moreno, Poesía española actual (1946), que «Felipe San Miguel $»^{5}$ dejó en evidencia a la luz de la nueva Antología consultada, donde se había superado el garcilasismo, que era la única apuesta oficial, y

empieza a hablarse de «poesía humana»y de «poesía social». ¿Qué quiere decirse con esto? Nadie parece saberlo. Nadie por lo menos llega a entenderse. Se apela al hombre, al hombre concreto y existencial, y en tanto que se hace esto, la insoslayable circunstancia histórica y social de ese hombre - es decir, la España traicionada que está doliéndole y la miseria pública en que se siente sumidosurge como tema de primera importancia en la lírica. Y entonces, Unamuno y Machado se imponen a todas las conciencias como grandes maestros, no sólo de poesía, sino también de verdad, de hombría y de valor español. Porque Unamuno y Machado, a diferencia de otros, nunca desencarnaron su canto, ni temieron comprometerse, ni trataron de flotar angélicamente por encima del pueblo que gime y llama (San Miguel, 1956: 17).

${ }^{4} \mathrm{Si}$ atendemos al contexto histórico, un año antes de la publicación de la Antología consultada se había producido la huelga de Barcelona, que abre una fractura dentro del férreo régimen franquista; un régimen que ya había sido obligado a ceder en cuanto a la libertad de prensa, gracias al respaldo que la ONU le brindara en 1950 con la revocación de los embargos. Max Aub realiza una antología en 1957 llamada Una nueva poesía española y establece precisamente los límites temporales en el lustro que va de 1950 a 1955 , subrayando la apertura que se produce en el interior, acorde a las reivindicaciones políticas y a los acontecimientos históricos en Europa.

${ }^{5}$ Según los investigadores James Valender y Gabriel Rojo Leyva, detrás del pseudónimo «Felipe San Miguel», escribiendo en la sección llamada «Crónicas de España», parece encontrarse Gabriel Celaya (1999: 265). 
Los nuevos poetas sociales encontraron en la figura de Miguel de Unamuno y Antonio Machado la manera de seguir entonando el canto que dejaron latente estos dos escritores sobre la tierra española. El propio Gabriel Celaya, clarifica su forma de entender la poesía en las palabras previas a la selección de los poemas: «Cantemos como quien respira. Hablemos de lo que cada día nos ocupa» (Ribes, 1952: 43), o de manera más clara: «Nada de lo que es humano debe quedar fuera de nuestra obra. En el poema debe haber barro, con perdón de los poetas poetísimos. Debe haber ideas, aunque otra cosa crean los cantores acéfalos» (Ribes, 1952: 44). Su poema «Un hombre» refleja ese momento en el que el poeta debe reconocerse como voz de lo cotidiano, pese al peligro constante de divagar, de sumirse en el limbo de su soledad:

Frente a un mundo en delirio, él [el hombre] se afirma en su paso.

No acaricia, no duda.

$\mathrm{Su}$ soledad heroica

no es un irse perdido por los limbos, cantando (Ribes, 1952: 48).

Las Españas selecciona su poema «Lo demás es silencio», también contenido en la propia antología. En el texto podemos destacar dos aspectos importantes: por un lado, el carácter descriptivo (realista) que emplea para referirse a diferentes estamentos de la sociedad, a los obreros, a las madres, además del énfasis que pone el poeta en el silencio, si es que con este se puede mantener viva la esperanza del cambio; y, por otro lado, el reconocimiento de la pertenencia a la burguesía o, al menos, a una clase acomodada desde la que observa el sufrimiento:

Quiero ser en los otros. Quiero morir por algo, perderme con provecho, descansar del que he sido, pensar que mis problemas personales son nada junto a esos tan pequeños, tan terribles, vulgares, del pan, de los zapatos o de las medicinas que a otros hombres les falta mientras yo filosofo (Celaya, 1953: 27).

El poema se encuentra recogido en la sección «Balcón a la poesía actual en España», en los números 23-25, de abril de 1953; junto a él, recoge Las Españas el poema «Lo que yo pienso sobre ello», de Eugenio de Nora, otro de los poetas seleccionados en la Antología consultada. Este poema también está entresacado de la Antología consultada, sin embargo, en la versión hemerográfica desaparece la dedicatoria que De Nora hacía a José María Valverde, otro de los poetas recogidos en la antología. Esta supresión responde a la línea ideológica que la revista sostenía. De hecho, en un ensayo publicado en ese mismo número, un anónimo escritor proveniente de la península, bajo el seudónimo de «Miguel Manrique», dice de este autor: «A Valverde, pesado, difuso y gazmoño, se le ha querido presentar como el gran poeta católico que el 
momento estaba pidiendo y que postulaba Luis Rosales, cuyo papel cobarde y pasivo en el asesinato de Lorca es bien conocido» (Manrique, 1953: 11). Como podemos observar, la selección de Las Españas es minuciosa en el acercamiento a la poesía del interior, es decir, en la decisión de a qué poetas acercarse y a cuáles otros no; ningún detalle, por mínimo que sea, queda expuesto a la arbitrariedad. En «Lo que yo pienso sobre ello», Eugenio de Nora aborda la mala conciencia que deben tener los que ahora gobiernan el país, que son los que cargan con la sangre y los muertos, termina con esta afirmación:

Pero ay de los malditos,

de los que están en deuda con cuerpos enterrados, de los que desnivelan la muerte con la muerte, y creen que el incidente ha terminado! (Nora, 1953: 27).

No encuentra motivo alguno para cerrar la historia, esta sigue su curso, pero, ¿cuál debe ser la postura del poeta? En la antología dice De Nora en torno a la posición que debe tener el poeta:

Los poetas de hoy, como casi todo el mundo, están o estamos a la defensiva. Parecen sentirse desarraigados, marginales, inútiles, con la timidez del que va a contar o cantar «un caso» - el suyo-, y siente que su caso no interesa. Hemos de cambiar de actitud, es decir, hemos de cambiar de vida. Hay que salir de los cuartos cerrados, de los ambientes de estufa, del aire malsano y mezquino de la «gente de letras». Tomar contacto y confundirse, identificarse con lo que está más lejos de nosotros, y con lo que está muy cerca, que a veces ignoramos aún más. ¿Hará falta recordar qué hicieron los más grandes? (Ribes, 1952: 154-155).

Como podemos observar la sensación de desarraigo no es exclusiva de los poetas del exilio, también lo es de los poetas del interior, y este sentimiento está ligado a la oportunidad de entonar su canto. Esto lo podemos observar en dos poemas antologados: el primero titulado "Canto», parece ofrecer una explicación de cómo este se encuentra en cada uno que lo enuncia, sin haberse ido a ningún sitio, porque ese canto está encerrado en «España, España, España. / Dos mil años de historia no acabaron de hacerte» y España es la de todos: «¡Ardiente, clara España!: / Tu ancha vida en tus hombres. Tu libertad por siempre» (Ribes, 1952: 164-166); pero en el segundo poema — «Poesía aquí»De Nora fija definitivamente su perspectiva temática, el horizonte en donde recuperar el canto:

No seguéis las palabras.

Contra ellos, yo canto hombres que tienen las caras como torsos con látigo: sonríen al dolor, pero miran 
el sol, y aprietan

los firmes dientes.

Y ya acabo.

(Esto no es un poema; son palabras

apretadas también, con saña.) Adiós. Es tiempo

de no plantar rosales. Acordaos (Ribes, 1952: 170).

Podemos observar la vocación narrativa de la poética, la prioridad del contenido sobre la forma, la declaración de guerra a través de las palabras y el canto, que tiene como perspectiva a los hombres que sufren y cargan el pasado sobre sus espaldas. Esto se ve muy bien en la primera estrofa del poema «A la inmensa mayoría», de Blas de Otero, también recogido en la Antología consultada:

Aquí tenéis, en canto y alma, al hombre

aquel que amó, vivió, murió por dentro

y un buen día bajó a la calle: entonces

comprendió: y rompió todos sus versos (Ribes, 1952: 192).

Victoriano Crémer es el otro poeta de la antología que tiene un espacio en Las Españas. Como dijimos, en este caso sus poemas no aparecen directamente dentro de una sección, como es el caso de Celaya y De Nora, o sueltos entre las páginas, sino que forman parte de dos reseñas críticas. De hecho, la reseña crítica dedicada al poemario La espada y la pared, publicado en San Sebastián, España (1949) aparece un número antes de que se inaugurara la sección «Balcón a la poesía actual en España». El crítico, Isidro Enríquez Calleja, afirma: «Realmente no todo es desierto en la entraña poética de la Península Ibérica bajo su actual régimen político. De vez en cuando adviértese un oasis confortador para nuestra sed de curiosidades literarias» (Enríquez Calleja, 1951: 23), y reproduce sus poemas «Las madres» y «Poemas sin sosiego». Estos dos poemas revelan el tedio del poeta y el hecho de dar a luz un hijo por parte de una madre -España- que no está en la mejor disposición de serlo. En la antología, Crémer es el más radical de todos en cuanto a la forma de atacar la poesía esteticista de la época: «esgrimirse sobre un canto rodado al sol del estío por el placentero afán de lanzar gorgoritos rítmicamente, mientras el hombre a secas trabaja, sufre y muere, es un delito» (Ribes, 1952: 63). Crémer también apela a su yo poético, precisamente en un poema llamado "Canción serena», que comienza de la siguiente forma:

No me dejéis así: Sorbido por la tierra

hondísima y vibrante como el clamor penúltimo;

con este olor maduro de soles y horizontes

abriéndome en el pecho un surco luminoso (Ribes, 1952: 67). 
La voz poética alude a la tierra como aquello que absorbe e impide entonar el canto del hombre, pero a ese hombre todavía le queda un «surco luminoso», una esperanza. Crémer habla de «sorbido por la tierra», un concepto que inmediatamente nos remite a Max Aub. En 1954, y como consecuencia de un curso que impartió, Aub publicó una antología llamada La poesía española contemporánea, en donde hacía un repaso de la misma hasta llegar a sus días. Dicho libro concluía con un capítulo llamado «Poesía soterrada». El crítico español reserva este término para explicar, en el último capítulo del mismo, la situación en la que se encuentra la poesía del interior de España en ese momento. Dice que hay una poesía al calor de la colección Adonaïs, «en la que se encierran algunos valiosos y muchas piruetas hechas en las orillas de Garcilaso o a la rémora de Vicente Aleixandre, olvidando que, como no podía menos que suceder, hay una poesía enterrada o, mejor, soterrada, en espera de luz» (Aub, 1954: 223 $)^{6}$. Pero, además, recoge el testimonio de alguien — que no dice quién- que agradece la llegada de poesías de León Felipe al interior de la península porque:

el acento desgarrado del desterrado, viva dentro o fuera, es el mismo siempre. Ese es el signo de las pocas canciones que por aquí se cantan, aunque sea en voz baja y entre amigos. Muchos, yo con ellos, quisiéramos decírselo así a León Felipe y, a la vez, darle las gracias, por lo que ha hecho por nosotros (Aub, 1954: 224-225) . $^{7}$

Aub, atento lector de la realidad poética y del diálogo que mantenía la revista Las Españas —en la que llegó a colaborar- con la creación poética en el interior de la península, acuña este término para ilustrar la manera en que el poeta sensible a la realidad de su tiempo aún está soterrado por las tendencias oficiales. Aub, de manera impresionista, disecciona la realidad: la poesía social — la soterrada - debe independizarse del padre - Vicente Aleixandre - y asumir la fortaleza, el desgarro, de León Felipe. Sin embargo, tres años serían suficientes para que Max Aub realizara una segunda antología, Una nueva poesía española (1950-1955) (1957), en donde matizara e incluso pusiera en entredicho algunos de los juicios expuestos en la primera. De hecho, el propio Aub afirma en el «Propósito» que es ahora cuando está en disposición de saber qué se encuentra bajo el término «poesía soterrada», los poetas que crecieron «apiñados, bajo la intolerancia, la ferocidad, la cursilería», pero que rompieron con ella y hoy defienden la España de Quintana, de Antonio Machado y de César Vallejo (Aub, 1957: 19). Entre esos poetas destaca Max Aub a Gabriel Celaya, Blas de Otero, José Hierro, Eugenio de Nora, Victoriano Crémer y

${ }^{6}$ Es interesante los matices que expone Naharro-Calderón en torno a los términos empleados en relación con los exiliados: desterrados, soterrados, transterrados, conterrados (Naharro-Calderón, 1994: 25-26).

7 En realidad, esto ya lo había escrito Max Aub en el número 5 de su Sala de Espera, pp. 2-3. 
Ángela Figuera, pero dice que hay cientos más, algunos de los cuáles asomarán tímidamente en este libro. Aunque llegue tarde al análisis de esta nueva poesía, Max Aub demuestra estar actualizado de las diferentes antologías ${ }^{8}$ que se han realizado especialmente en España, de hecho, en su libro de 1954 confiesa:

Me puse a hojear una antología, y he aquí que, de pronto, me di cuenta de que ya no era la misma [poesía], siéndolo; [...] Aquellos libros, que yo recordaba separadamente, formaban un todo en el curso de la historia, adquiriendo otra proporción; [...] todos éramos distintos, siendo los mismos (Aub, 1954: V).

En su segundo libro, Max Aub da a conocer otra antología del interior sobre la que no existe testimonio alguno dentro de Las Españas, se trata de la Antología cercada (1947), publicada por diferentes poetas, mayoritariamente canarios, que constituye un primer paso para el establecimiento de la estética realista en la poesía (Aub, 1957: 47). Las antologías de Max Aub no lo son de manera estricta, sino que forman parte de diferentes cursos que impartió en México, por lo que están llenas tanto de los propios poemas de los autores, como de datos históricos y testimonios de la época, además de presentar una estructura orientativa. En la de 1957 detectamos que una gran parte de los testimonios de los poetas protagonistas que reúne son extraídos precisamente de la Antología consultada, que por supuesto Max Aub tenía tan presente. Esta antología es, como fue para Las Españas, el motivo principal para que el recopilador matizase muchos de los juicios que había vertido tan solo tres años antes.

Volviendo al combativo Crémer que se presenta en la Antología consultada, este confiesa en su preludio que «Poesía es comunicación (Vicente Aleixandre). No resta, pues, sino descubrir el ser al que dirigir nuestro mensaje...» (Ribes, 1952: 65). El poeta reconoce una paternidad hacia Aleixandre en la manera de entender la poesía, algo que está latente en el resto de poetas sociales recogidos en la antología, pero que ninguno se atreve a decirlo de manera clara. El poemario Sombra del paraíso de Vicente Aleixandre — como hemos señalado anteriormente- no había quedado bien parado por la crítica de Las Españas. Pero Max Aub, con algo más de perspectiva, ya intuía la necesaria figura de Aleixandre, que había auspiciado a la nueva generación poética. En la primera antología de 1954, Max Aub —-seguramente muy influido por el juicio crítico de Las Españas - realiza un esfuerzo por comprender el papel de la poesía de

${ }^{8}$ Aub se podría referir no solo a la importante Antología consultada de la joven poesía española (1952), de Francisco Ribes, sino también a la Antología de poetas españoles contemporáneos (1945), de César González Ruano, y a la Poesía española actual (1946), de Alfonso Moreno. Después de estas, se publicaron otras que ayudaron a comprender su papel decisivo en la conformación del grupo de poetas conocido como sociales: Veinte poetas españoles (1955), de Rafael Millán; Veinte años de poesía española (1960), de José María Castellet; y Poesía social (1965), de Leopoldo de Luis. 
Aleixandre, a la que tilda de poesía de liberación personal; intenta incluso justificarlo en las heridas que puede tener por una felicidad huida, quizá por la España que se perdió (Aub, 1954: 157-159). Es comprensible, pues, la reprobación que hacen de la poética y la figura de Aleixandre en Las Españas, seguramente por ser un poeta que eligió quedarse en la España invadida, a diferencia del resto de escritores que llevan a cabo la revista. Pero no cabe duda del papel fundamental que Aleixandre tuvo en la formación de esta nueva generación que se pone en escaparate gracias a la Antología consultada. Curiosamente, es uno de los poetas tradicionales que recoge la antología, Rafael Morales, el que confiesa que el gran Vicente Aleixandre le dijo una vez que el poeta que escribe para sí mismo, lo que hace es suicidarse por falta de destino (Ribes, 1952: 126). Quizás por eso Aub tenga cierta condescendencia con el autor de Sombra del paraíso y alegue su falta de valentía para denunciar. Además, el propio Eugenio de Nora, él sí autor destacado entre los «sociales» por Las Españas, reconoce el papel de Aleixandre en su formación poética9.

Como ya hemos visto, la poesía de Crémer, Celaya y De Nora, pasa a incluirse en las páginas de Las Españas. Sin embargo, la de Blas de Otero y la de José Hierro, no tienen la misma suerte. Pese a ser considerados también como poetas sociales, la revista los relega a un segundo plano. En el caso de Blas de Otero es comprensible porque en su primera etapa aún no se había liberado de cierto tradicionalismo. De hecho, en la Antología consultada afirma: «Creo en la poesía social, a condición de que el poeta (el hombre) sienta estos temas con la misma sinceridad y la misma fuerza que los tradicionales» (Ribes, 1952: 180). El caso de José Hierro, poeta que estuvo condenado a varios años de prisión, es quizá menos evidente, por la línea clara de su reivindicación, que coincide plenamente con los ideologemas de la revista. A pesar de este abandono por el que pasa la figura de Hierro, tanto en el número 4-5 de la segunda versión de Las Españas, que se llamó «Diálogo de las Españas», como en una sección que lleva el mismo nombre que tenía en la tradicional revista — «Balcón a la poesía española actual»—, publican «El amor» (Hierro, 1963: 17). Es extraño, pues, que José Hierro sea el último poeta incluido en Las Españas, porque en la Antología consultada es el que hace una reflexión más profunda

9 «Sin duda yo he admirado profundamente, y admiro, y debo mucho, a Machado y Unamuno, a Juan Ramón, a todo el grupo que cronológicamente abre Salinas y cierra Luis Cernuda, y me he formado en la amistad y la camaradería generosa de algunos de ellos, Dámaso y Aleixandre ante todo» (De Nora en Ribes, 1952: 154). Estas palabras las reproduce Max Aub en su segunda antología, la de 1957. Es importante el reconocimiento que hacen estos autores especialmente de las figuras de Antonio Machado y Juan Ramón Jiménez, José María Naharro-Calderón afirma: «las actitudes divergentes mantenidas por Antonio Machado y Juan Ramón Jiménez, durante aproximadamente dos década antes del inicio de la guerra civil producirán finalmente sus frutos cuando los poetas innovadores en las décadas del cuarenta y del cincuenta vuelvan sus ojos hacia las estéticas de estos dos precursores» (Naharro-Calderón, 1994: 120). 
sobre el proceso global de creación poética en el interior que, como ya hemos ido viendo a lo largo del artículo, está muy ligado a la canción, a la tierra y a la flor o el árbol. Una de las poesías del poeta madrileño seleccionadas para la antología se titula «Ya no cantaré nunca más» y comienza y termina prácticamente con la misma estrofa, que reproducimos a continuación, junto con una estrofa intermedia:

No cantaré ya nunca más. El canto

se me ha secado en la garganta.

Como una rosa.

$[\ldots]$

Ay, las canciones sin medida.

La medida sin notas, sin palabras.

Ay, las columnas en que puse

el peso dulce de mis alas.

[...]

No cantaré ya nunca más. El canto

se me ha secado en la garganta.

Se ha dormido en mi corazón

como una rosa. (Ribes, 1952: 119-121).

En el transcurso del poema, Hierro desarrolla todos los elementos que pueden suponer un llamado al canto, que a la vez es un recorrido autobiográfico por diferentes fases de su pasado, para encontrar en dónde pudo haberse apagado la canción. Al llegar a la última estrofa, el canto suma un nuevo alojamiento: el corazón. El poeta ha buscado el canto en la voz, pero este se había secado en la garganta; sin embargo, si uno escarba hasta el corazón, se cerciora de que solo estaba dormido, como una rosa ${ }^{10}$, dispuesta a florecer, a que encuentre ahí cobijo su raíz. En la explicación que antecede a la selección de los poemas, afirma José Hierro lo siguiente con respecto al canto:

El poeta siente como si le enterneciera el recuerdo de una música que escuchó en el pasado. Su propia alma le canta en los oídos. Quisiera cantar esa música a los demás, hacerles experimentar la misma emoción que a él le llena. Pero su situación es semejante a la de un hombre que recuerda imprecisamente una canción y necesita que alguien comience a cantársela para poder proseguir él (Ribes, 1952: 100).

${ }^{10}$ En su libro-antología de 1957, Max Aub expone la polémica que se dio en la época anterior en torno a la metáfora de la rosa para explicar la poesía. Fue Juan Ramón Jiménez el que primero afirmó: «No le toques ya más / que así es la rosa», mientras que León Felipe le contestó: «Deshaced este verso, / quitadle los caireles de la rima, / el metro, la cadencia / y hasta la idea misma. / Aventad las palabras, / y si después queda algo todavía, / eso / será la poesía». Dice Aub a continuación: «Conceptos dispares. Ambos dieron su fruto; más temprano el del Andaluz universal; más tardío, más cercano a nosotros, el del Castellano errante» (Aub, 1957: 164-165). 
Como podemos observar, Hierro apela al contenido histórico que posee el hombre, al recuerdo de la música que quedó allí para que continuara en el devenir del tiempo. Pero, ¿dónde buscamos esa música? El poeta nos ofrece una pista un poco más adelante: «Confieso que detesto la torre de marfil. El poeta es obra y artífice de su tiempo. El signo del nuestro es colectivo, social. Nunca como hoy necesitó el poeta ser tan narrativo» (Ribes, 1952: 106). La música, pues, se puede encontrar en la tierra que todos comparten, donde está inmanente la tradición literaria, porque es a la propia tierra a la que los antiguos poetas cantaban.

Como hemos podido comprobar, el cambio que opera Las Españas desde la publicación de la Antología consultada es absoluto, hasta el punto de que en la crítica que la propia revista hace de la antología, a cargo de Manuel Bonilla Baggetto, este reconoce el papel patriarcal de Vicente Aleixandre —ahora síen esta nueva generación, junto con Antonio Machado. El primero, en cuanto a la forma, la amplitud del léxico, la adjetivación y el segundo, en cuanto a la manera clara de reflejar los temas. Se atreve a afirmar lo siguiente: «Leyendo a Nora y a José Hierro se ve cómo en España los poetas se juegan la vida y dicen mucho más — donde es difícil y peligroso decirlo—, que otros que desde aquí, en su cómodo refugio, creen hacer poesía revolucionaria por el solo hecho de lanzar panegíricos» (Bonilla Baggeto, 1953: 39). La aseveración ejemplifica el cambio de perspectiva operado por Las Españas y aprovecha también para lanzar un ataque a los poetas del exilio. La paulatina modificación de la revista en lo que respecta a la comunidad de escritores del interior de España termina de apuntalarlo el ensayista Daniel Tapia. En «España a la vista: la generación del 29 y los heterodoxos en el exilio», Tapia plantea, desde la tercera persona del plural, que los exiliados se la han pasado añorando el regreso a la España que dejaron hace diecisiete años atrás, pero cree que en esa espera están fallando al propio país natal:

Estamos en vísperas de nacer o de resucitar, no de recuperar nada ni de resarcirnos de nada. Conviene que vayamos cambiando nuestro sentido de acreedores, de acreedores de España, en que nos hemos venido considerando, por otro más humilde y profundo de deudores. Nos debemos a España... y España no nos debe nada (Tapia, 1956: 42).

Las Españas no solo reservó sus espacios poéticos a algunos de los autores recogidos en la Antología consultada, fue más allá e incluyó a otros poetas del interior que no habían sido tan destacados. Es el caso de Vicente Carrasco y Leopoldo de Luis, que en la Antología de 1952 fungieron simplemente como expertos consultados para elaborar el repertorio. Poemas de ambos autores están recogidos en la sección «Balcón a la poesía actual en España». Este hecho demuestra que el vínculo que se comenzaba a desarrollar entre los dos grupos de escritores iba más allá de lo explícito. La Antología consultada había abier- 
to un interés inmediato en los intelectuales del exilio por conocer todo el campo poético que se estaba desarrollando en España.

En Las Españas, Vicente Carrasco nos muestra una visión diáfana de lo que considera que es la poesía. La canción, en el poema titulado «Un... (Canto a lo indeterminado)», se traduce como la inspiración que arriba para henchir al mundo - paisaje sumergido en las tinieblas-, de esperanza. En la búsqueda de ese «un» surge la vida:

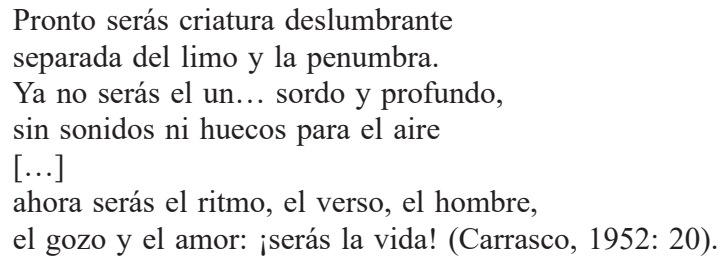

El tono del poema nos brinda una sensación de bienestar que contrasta enormemente con algunos de los poemas de corte social que hemos analizado anteriormente, sobre todo en lo que respecta a la poética de Celaya. El hombre y su realidad, ya sea de forma celebratoria o de forma funesta y dolorida, encuentran en la poesía «el único refugio posible contra la agresiva mezquindad ambiente» (Ribes, 1952: 9).

La canción de Leopoldo de Luis, en cambio, nos presenta a una voz poética enfurecida, aferrada al dolor cotidiano que sufren los hombres; «la tierra duele» nos dirá en la primera parte de su «Tríptico», publicado en el número 23-25 de la revista. La imagen que hemos venido rastreando a través de todas estas poéticas presentes en Las Españas y en la Antología Consultada -tierra-canción- es utilizada por un poeta que estando en España se siente desterrado, firmemente desterrado:

mía esta tierra, mía esta simiente.

Mío este llanto y estas cicatrices.

$[\ldots]$

Esta tierra violenta, este destierro es mío.

Lo defiendo con uñas y dientes (Luis, 1953: 13-14).

Por todo lo expuesto anteriormente, la Antología consultada produjo un cambio determinante en la línea editorial de Las Españas. Este cambio, junto con otras circunstancias de interés político, encontró la oposición de una parte del Partido Comunista Español en México. La vocación de la revista había sido aunar todas las voces del exilio republicano para visualizar la unión de la intelectualidad y proyectarse sobre el interior de España, contrarrestando a su vez los intentos del régimen franquista por «colonizar» culturalmente América, especialmente por medio de la creación del Instituto de Cultura Española en México. Al inicio de la aventura, ilustres comunistas combativos ante el régi- 
men dictatorial formaron parte de la revista, entre los cuales destacamos a Juan Rejano y a José Renau. Sin embargo, en un momento dado dejaron de colaborar e incluso atacaron frontalmente el hecho de dar a conocer en México cualquier manifestación artística que se produjera en el interior de España. En una entrevista, Anselmo Carretero, uno de los promotores iniciales de la revista, cuenta que, aunque eran muy de izquierdas, siempre estuvieron en contra de la prepotencia y del dogmatismo del Partido Comunista, pese a que al principio guardaban con él una relación muy cercana, especialmente porque tenía mucha fuerza en la emigración. Sin embargo, la colaboración tuvo un fin a raíz de un «ataque feroz, feroz» del Partido Comunista a la revista: «cuando se dieron cuenta de que no podían apoderarse de ella [de la revista], entonces hicieron lo que por órdenes superiores hacían siempre... [...]. Y Renau, que nos había estado ayudando hasta entonces, salió de repente con el artículo, "La causa de España y los especuladores del derrotismo”» («Entrevista con Anselmo Carretero», 1999: 311-312).

Curiosamente, Juan Rejano también mantuvo una polémica con Max Aub en relación con el boletín que este editó entre 1948 y 1952, Sala de Espera. Aub, ante las críticas recibidas por Roces y Rejano en torno al título de su boletín, les dirige una carta el 4 de julio de 1948, explicándoles el sentido que había querido dar al título de estos cuadernillos:

Es muy fácil hacer chistes, torcer y retorcer la intención o la realidad ajena. No os hubiese escrito estas líneas si no me doliese que los que considero como mis amigos den tan mala interpretación a mi enclenque sueño, mi amarga gota de agua [...]. Pese a lo que pueda parecer en su soledad, «Sala de Espera» no es esfuerzo singular, sino que tiende a encajarse modestamente, pero hombro con hombro, hombre con hombre, solidariamente, con el trabajo de todos por la reconquista de nuestra España ${ }^{11}$.

Como podemos deducir, Roces y Rejano se burlan precisamente de lo mismo de lo que les acusaba Daniel Tapia en su ensayo de Las Españas de 1956: de permanecer a la espera. Por otro lado, Juan Rejano también critica a Max Aub por elogiar a los poetas del interior en publicaciones mexicanas:

Tengo la impresión, amigo Max, de que algunos de los escritores españoles del destierro que mantenéis correspondencia con los del interior de España no os dais cabal cuenta del delicado asunto que tenéis entre manos. Lo mejor que podemos hacer por aquellos compatriotas y amigos no es sahumarlos con el incienso del elogio [...]. Nuestra ayuda debe consistir, sobre todo, en facilitarles constantemente información, orientaciones, elementos críticos, de los cuales carecen casi en absoluto. No olvidemos que tales compañeros viven en una cárcel adonde no puede llegar el aire de la libertad y de la cultura (Rejano, 2000: 179-180).

${ }^{11}$ Carta de Max Aub a Juan Rejano y Wenceslao Roces, 4 de julio de 1948. Fundación Juan Rejano [consultada electrónicamente el 10 de mayo de 2014]. 
Detrás de esta actitud de Rejano se encuentra también la disconformidad con el cambio de parecer en Las Españas con respecto al hecho de incluir a los poetas del interior en la sección de «Balcón a la poesía actual en España». Rejano y el Partido Comunista se mantuvieron firmes ante la aseveración de que el canto se lo habían llevado ellos y pensaban que los poetas del interior solo arrojarían luz sobre las tinieblas que el régimen había provocado. Pero la realidad era otra: la poesía estaba ligada a la tierra y, gracias a esta, surgía la tradición literaria en la voz del poeta del interior; también el exiliado había mantenido aquella canción, pero una canción ligada a la memoria. El desencadenante concreto de la polémica entre Rejano y Aub había sido el artículo de este, «Un nuevo gran poeta español: Ángela Figuera Aymerich» (Meyer, 2007: 536-537) ${ }^{12}$, en el cual consideraba a esta última dentro de la nueva hornada de poetas sociales. Por tanto, Ángela Figuera es la única que Max Aub añade al grupo de poetas sociales que acoge la revista Las Españas, y todo gracias a la Antología consultada de 1952. Tan solo un año más tarde del reconocimiento que le brinda Max Aub, León Felipe escribió el prólogo de Belleza cruel (1958), libro que Ángela Figuera publicó en México, seguramente para evitar la censura. León Felipe afirmaba:

Con estas palabras quiero arrepentirme, Ángel Figuera Aymerich... de cosas que uno ha dicho, de versos que uno ha escrito... [...]

Fue éste un triste reparto caprichoso que yo hice, entonces, dolorido, para consolarme. Ahora estoy avergonzado. Yo no me llevé la canción. Nosotros no nos llevamos la canción. Tal vez era lo único que no nos podíamos llevar: la canción, la canción de la tierra, la canción que nace de la tierra, la canción inalienable de la tierra. Y nosotros, los españoles del éxodo y del viento... iya no teníamos tierra!

Vosotros os quedasteis con todo: con la tierra y la canción. [...]

Al final todo se hizo grito vano, lamento hinchado, blasfemia sin sentido, palabras de un idiota llenas de estrépito y de furia que se perdieron como burbujas de hiel en el vacío... Y nos quedamos luego todos mudos... Los mudos fuimos nosotros... ¡Los desterrados y los mudos!

De este lado nadie dijo la palabra justa y vibrante. Hay que confesarlo: de tanta sangre a cuestas, de tanto caminar, de tanto llanto y de tanta injusticia... no brotó el poeta.

Y ahora estamos aquí [...], oyéndoos a vosotros cantar: con esperanza, con ira, $\sin \operatorname{miedos} . . .[\ldots]$

Esa voz... esas voces... Dámaso, Otero, Celaya, Hierro, Crémer, Nora, de Luis, Ángela Figuera Aymerich... los que os quedasteis en la casa paterna, en la vieja

12 Novedades. México en la Cultura, 8-IV-1956. Aunque Rejano, en su carta pública dirigida a Aub, habla del artículo publicado en el suplemento cultural de Novedades, nosotros tenemos dudas de que se refiriera concretamente a este, ya que expone algunas características cuya correspondencia no hallamos en dicho texto, por lo que no sería extraño que hablara de otra publicación, aunque siempre teniendo como tema común a Ángela Figuera Aymerich. 
heredad acorralada... Vuestros son el salmo y la canción. LEÓN FELIPE. México, D.F., junio, 1958 (León Felipe, 1958: 9-11).

Habían pasado casi veinte años desde que León Felipe pronunciase aquellas palabras de rapto para la canción española. El arrepentimiento que expresa el poeta, a diez años de su muerte, es indicativo de que el camino y el diálogo entre los poetas del interior y los del éxodo había surtido efecto. La imagen voz-silencio vinculada con la canción-tierra se invierte, y ahora son los exiliados - al decir del poeta - los desterrados y los mudos. Un remordimiento parecido inunda la poética de Juan Rejano en los últimos años de su vida, previos a su intención de regresar a suelo español. En 1959, por ejemplo, escribe el poema titulado «Saludo a los nuevos poetas de España» que, dadas las circunstancias históricas, resulta más que significativo. A pesar de la militancia y de las fuertes críticas que mantuvo Rejano respecto a la poesía del interior de España, y de las diferencias que sostuvo con algunos de los escritores que apoyaron la nueva poesía nacida desde la España en cautiverio, al final, en él pudo más la voz del poeta que la del militante. Debido a lo entrañable del poema, hemos decidido reproducirlo en su totalidad:

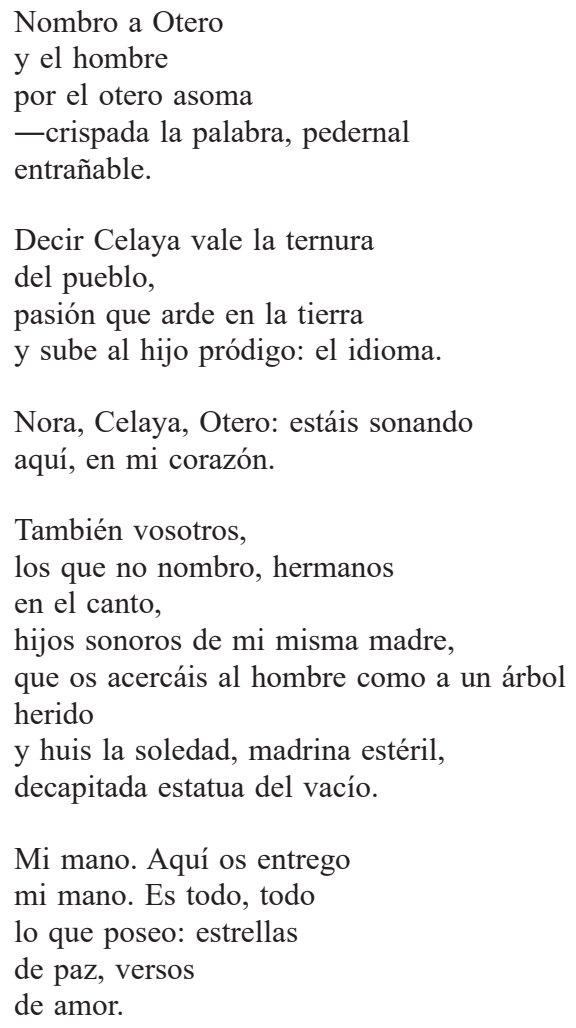




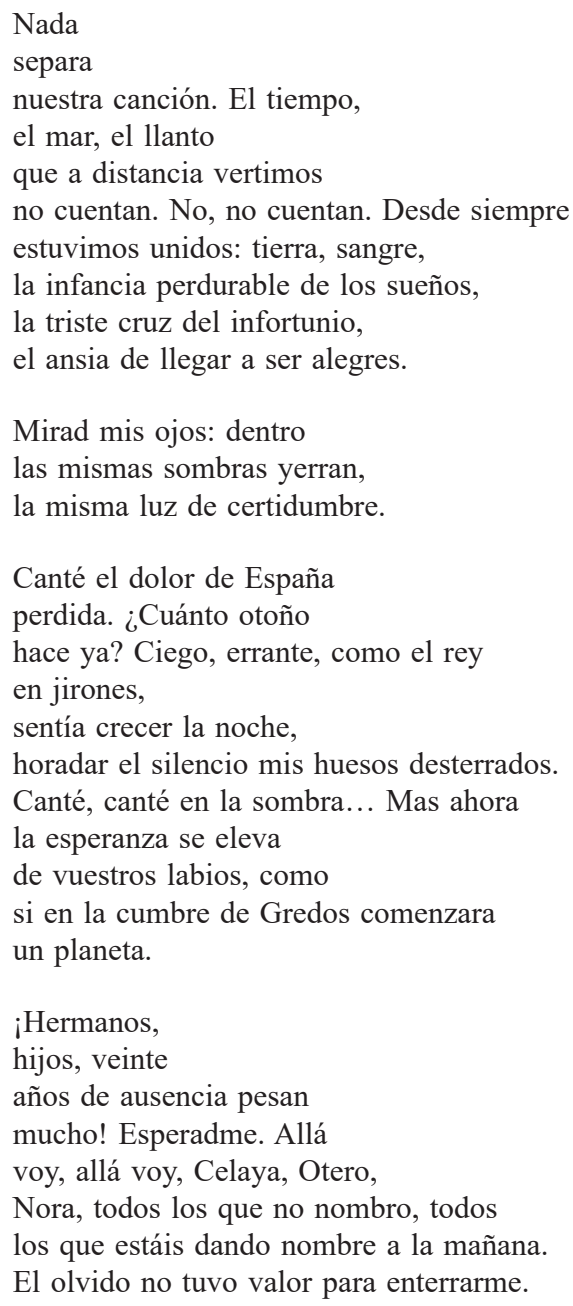

Rejano, resistente a la recepción de la poesía del interior en el exilio, etiqueta a los autores más relevantes de la poesía social como «hermanos en el canto». Así, acorta el largo trecho existente entre los poetas españoles de uno y otro continente: nunca la canción abandonó la tierra, tampoco estuvo de manera exclusiva en el continente americano, porque «desde siempre estuvimos unidos: tierra, sangre, la infancia perdurable de los sueños». Este poema es la prueba final de que el discurso poético desborda y rompe todas las estructuras ideológicas que se habían predeterminado. Este trabajo ha pretendido recoger las huellas de un itinerario transoceánico a través de las letras españolas: el itinerario del canto. Tomás Segovia tuvo razón al declarar, muchos años después de la acalorada discusión sobre quiénes se quedaron con la canción, que 
«da lo mismo que la canción sea de León Felipe o de Ángela Figuera mientras la Palabra no sea de ninguno de los dos. Es en efecto el poeta el que pertenece a la Palabra y no al revés» (Valender, 1998: 425).

\section{FUENTES PRIMARIAS}

Arana, José Ramón (1947). «Voces, ecos, sombras», Las Españas. 3, pp. 10-11.

Arana, M. ${ }^{a}$ Dolores (1947). «Los Libros. Vicente Aleixandre, Sombra del paraíso», Las Españas. 6, p. 4.

Bonilla Baggeto, Manuel (1953). «La joven generación poética española», Las Españas. 23-25, p. 39.

Brook, Paulita (1946). «César González Ruano. Antología de poetas españoles contemporáneos. Editorial Gustavo Gili, Madrid, 1945». Las Españas. 1, p. 5.

Carrasco, Vicente (1952). «Un... (Canto a lo indeterminado)», Las Españas. 21-22, p. 20.

Celaya, Gabriel (1953). «Lo demás es silencio (Fragmento)», Las Españas. 23-25, p. 27.

Domenchina, Juan José (1949). «La sombra desterrada», Las Españas. 12, pp. 8-9.

Durán Gili, Manuel (1947). «Elegía», Las Españas. 4, p. 13.

«Editorial» (1946). Las Españas. 1, p. 2.

Enríquez Calleja, Isidro (1951). «La espada y la pared», Las Españas. 19-20, p. 23.

Hierro, José (1963). «El amor», Diálogos de las Españas. 4-5, p. 17.

Luis, Leopoldo de (1953). «Tríptico», Las Españas. 23-25, pp. 13-14.

Manrique, Miguel (1953). «Crónicas de España. Breve esquema de la literatura en la España Franquista», Las Españas. 23-25, p. 11.

Moreno Villa, José (1946). «A veces oigo», Las Españas. 1, p. 1.

Nora, Eugenio de (1953). «Lo que yo pienso de ello», Las Españas. 23-25, p. 27.

Redacción (1946). «Recuadro sin título», Las Españas. 1, p. 7.

Redacción (1950). «Farsa y verdad», Las Españas. 14, p. 13.

Rius Azcoitia, Luis (1946). «Paisaje», Las Españas. 2, p. 6.

San Miguel, Felipe (1956). «Crónica de España. La España de hoy en su poesía real», Las Españas. 26-28, p. 17.

Tapia, Daniel (1948a). «Las castañas en el fuego», Las Españas. 8, p. 10.

Tapia, Daniel (1948b). «La otra mujer de Lot», Las Españas. 9, p. 11.

Tapia, Daniel (1956). «España a la vista: la generación del 29 y los heterodoxos en el exilio», Las Españas. 26-28, p. 42.

\section{BIBLIOGRAFÍA CITADA}

Andújar, Manuel (1999). «Carta de Manuel Andújar», en James Valender y Gabriel Rojo Leyva (ed.), Las Españas. Historia de una revista del exilio (1946-1963). México: El Colegio de México, pp. 298-302.

Aub, Max (1954). La poesía española contemporánea. México: Imprenta Universitaria.

Aub, Max (1957). Una nueva poesía española (1950-1955). México: Imprenta Universitaria. «Entrevista con Anselmo Carretero» (1999), en James Valender y Gabriel Rojo Leyva (ed.), Las Españas. Historia de una revista del exilio (1946-1963). México: El Colegio de México, pp. 304-322. 
Jato, Mónica (2004). El lenguaje bíblico en la poesía de los exilios españoles de 1936. Kassel: Reichenberger.

León Felipe (1958). «Palabras...», en Ángela Figuera Aymerich, Belleza cruel. México: Compañía General de Ediciones, pp. 7-11.

León Felipe (1963). Obras Completas. Adolfo Ballano Bueno y Andrés Ramón Vázquez (ed.); Guillermo de Torre (pról.). Argentina: Losada.

Meyer, Eugenia (ed. y estudio preliminar) (2007). Los tiempos mexicanos de Max Aub. Legado periodístico 1943-1972. Madrid: Fondo de Cultura Económica / Fundación Max Aub.

Naharro-Calderón, José María (1994). Entre el exilio y el interior: el «entresiglo» y Juan Ramón Jiménez. Barcelona: Editorial Anthropos.

Rejano, Juan (1988). La mirada del hombre. Aurora de Albornoz (estudio preliminar). Barcelona: Anthropos.

Rejano, Juan (2000). Artículos y ensayos. Manuel Aznar Soler (ed., estudio introductorio y notas). Sevilla: Renacimiento.

Ribes, Francisco (1952). Antología consultada de la joven poesía española. Santander: Artes Gráficas de los Hermanos Bedia.

Valender, James (1998). «La poesía del interior de España vista desde el exilio mexicano (1939-1959)», en Manuel Aznar Soler (ed.), El exilio literario de 1939. Actas del primer Congreso Internacional (Bellaterra, 27 de noviembre-1 de diciembre de 1995). Barcelona: Gexel, vol. 2, pp. 409-425.

Valender, James y Gabriel Rojo Leyva (ed.) (1999). Las Españas. Historia de una revista del exilio (1946-1963). México: El Colegio de México.

Fecha de recepción: 10 de febrero de 2015.

Fecha de aceptación: 26 de mayo de 2015. 